\title{
ISOLATION AND IDENTIFICATION OF BACTERIAL CAUSATIVE AGENTS FROM CATTLE WHICH SUFFER FROM RESPIRATORY MANIFESTATIONS
}

\author{
Talat Hamed Shesah Badier \\ Animal Health Institute, Dokki Kafr El-Sheikh Vet. Lab. Branch
}

\begin{abstract}
This investigation was carried out to determine the incidence of bacterial respiratory pathogens in cattle. A total 300 samples were collected from the respiratory system of 200 sample of 100 slaughtered cattle, 50 apparently healthy cattle and 50 animals with respiratory affections.

Bacteriological examination of these samples from recent slaughter and living cattle resulted in isolation of 150 (65.22\%) and 80 (37.78\%), respectively. The results showed that 230 animals were positive with an incidence of (76.67\%), of which some cases showed mixed infection and few had one bacterial isolate in a pure form in culture. The total numbers of isolates were 214 of which 70 (28.09\%). Staphylococcus spp. 90 (42.06\%), E. coli, 25 (11.66\%) Proteus spp. 15 (7.01\%), Pasteurealla spp., 9 (4.21\%), Citrobacter spp. and 15 (7\%) Pseudomonas spp. Besides, the antibiotic sensitivity test was done in vitro on some pathogenic respiratory bacterial isolates. Most microorganism were sensitive to enerofloxacin.
\end{abstract}

\section{INTRODUCTION}

Cattle are considered the most important farm animals, cattle are the main source of milk, meat and hides. Cattle are susceptible to many respiratory pathogens, the most serious of them are the bacterial pathogens (Blood and Henderson, 1979). 
Many aerobic bacterial agents causes respiratory disorders in cattle. Actinomyces pyooens, P. haemolytica, E. coli, Ps. aeruginosa, Haemophilus and Salmonella were incriminated in the aetiology of respiratory diseases in cattle (Fischer, 1975, Garoiu et al., 1982, Sing and Singh, 1980 and Barboura, 1997).

Indole-negative pasteurllae, producing dermonecrotic pasteurella toxin were isolated from the nose of calves in a herd with enzootic bronchopneumonia Ehlers et al. (1993). On the other hand, virtalal et al. (1996) suggested that a synergistic effect between mycoplasma species and $P$. multtiocida which were isolated from respiratory samples of cattle.

P. muttocida and P. haemolytica were covered from pneumonia lungs of stressed feeder calves than died from bovine respiratory tract disease, (Putdy et al., 1997). Six strains of Corynebacterium spp. were isolated from 137 slaughtered cattle with an incidence of $4.5 \%$ El-Enbaw (1986).

Examination of 33 diseased cattle lungs were done by Collins et al. (1988) and the infection was attributed to Pasteurella species, mycoplasma and S. aureus.

This study was done to show the predominant respiratory bacteria among cattle.

\section{MATERIALS AND METHODS}

A total of 300 samples were collected from respiratory system of cattle (200 samples were from 100 slaughtered cattle, 50 of apparently healthy cattle and 50 from diseased ones). Samples were collected from cattle were nasal swabs, tracheal swabs, laryngeo tracheal swabs and 
heart blood. The samples collected by sterile cotton swabs. From freshly slaughtered cattle and immediately transferred to the laboratory for cultivation. Lung samples were collected from congested lung areas of the slaughtered cattle, in sterile plastic bags and transported on ice box for bacteriological examination. Collected samples were inoculated onto enrichment media (peptone water, nutrient media and loffers media), then inoculated onto nutrient agar, blood agar, mannitol sal agar and MacConkey agar plates and incubated aerobically at $37^{\circ} \mathrm{C}$ for $24-48$ hours. Suspected growing colonies were characterized on the basis of morphological and colonial appearance according Finegold and Martin, (1982). The pure colonies were identified biocemcially according to Koneman et al. (1983) and Kries and Holt (1989). The pathogenicicity and virulence of some isolated strains $P$. multocida to mice were determined according to Wilson and Miles (1975). Susceptibility of the most predominant pathogenic isolates to different chemotherapeutic agents was tested the disc diffusion method according to Finegodl and Matin (1982).

\section{RESULTS}

Table (1) results revealed that the bacterial isolates were 150 $(65.22 \%$ and $80(34.78 \%)$ in recent slaughtered and living cattle animals respectively. Table (2) illustrated that the number and incidence of bacterial isolates in 100 tracheal swabs and 100 lung tissues was 80 $(53.33 \%)$ and $70(46.67 \%)$, respectively. While Table (3) revealed that number and incidence of bacterial positive samples in apparently and diseased cattle were 0 (44.44\%) and 50 (55.56\%). 
Table (1): Rate of bacterial isolation from respiratory system of cattle.

\begin{tabular}{|c|c|c|c|c|c|}
\hline \multirow{2}{*}{ Source and types of samples } & \multirow{2}{*}{$\begin{array}{c}\text { No. of } \\
\text { samples }\end{array}$} & \multicolumn{2}{|c|}{ Positive } & \multicolumn{2}{|c|}{ Negative } \\
\hline & & No & $\%$ & No & $\%$ \\
\hline Slaughtered & - & & & & \\
\hline Cattle (different parts & - & & & & \\
\hline of resp. systems) & 200 & 150 & 75 & 50 & 25 \\
\hline Living cattle (nasal swabs) & 100 & 70 & 70 & 30 & 28.57 \\
\hline Total & 300 & 230 & 76.67 & 70 & 23.33 \\
\hline
\end{tabular}

Table (2): Types of infection and incidence of bacteriological positive cases in slaughtered cattle.

\begin{tabular}{|c|c|c|c|c|c|}
\hline \multirow{2}{*}{ Source and types of samples } & \multirow{2}{*}{$\begin{array}{c}\text { Total no. of } \\
\text { samples }\end{array}$} & \multicolumn{2}{|c|}{ Positive } & \multicolumn{2}{|c|}{ Negative } \\
\hline & & No & $\%$ & No & $\%$ \\
\hline Trachea swabs & 100 & 80 & 53.33 & 20 & 40 \\
\hline Lung tissues & 100 & 70 & 46.67 & 30 & 60 \\
\hline Total & 200 & 150 & 75 & 50 & 25 \\
\hline
\end{tabular}

N.B. No. of isolates ( \%).

Table (3): Results of bacteriological examination of living cattle.

\begin{tabular}{|c|c|c|c|c|c|}
\hline \multirow{2}{*}{ Source and types of samples } & \multirow{2}{*}{$\begin{array}{l}\text { Total no. of } \\
\text { samples }\end{array}$} & \multicolumn{2}{|c|}{ Positive } & \multicolumn{2}{|c|}{ Negative } \\
\hline & & No & $\%$ & No & $\%$ \\
\hline Apparently healthy cattle & 50 & 40 & 44.44 & 10 & 100 \\
\hline Diseased cattle & 50 & 50 & 55.56 & 0 & 0 \\
\hline Total & 100 & 90 & 90 & 10 & 100 \\
\hline
\end{tabular}

Table (4) revealed the presence of E. coli 90 (42.06\%) and Staph. aureus 60 (28.04\%) and Citrobacter $9(4.21 \%)$.

Table (5) illustrate that bacterial isolates in slaughtered cattle were $175(58.41 \%)$ and in living animals were 89 (41.59). 
Isolation And Identification Of Bacterial Causative Agents ...

Table (4): The incidence and occurrence of pathogenic and potentially pathogenic bacteria in samples from examined cattle.

\begin{tabular}{|c|c|c|c|c|c|c|c|c|}
\hline \multirow{3}{*}{ Bacterial species } & \multirow{2}{*}{\multicolumn{2}{|c|}{ Slaughtered (200) }} & \multicolumn{4}{|c|}{ Living cattle (100) } & \multicolumn{2}{|c|}{ Total } \\
\hline & & & \multicolumn{2}{|c|}{ Healthy cattle (50) } & \multicolumn{2}{|c|}{ Diseased ones (50) } & \multirow{2}{*}{$\begin{array}{l}\text { No. of } \\
\text { isolates }\end{array}$} & \multirow{2}{*}{$\begin{array}{c}\text { Isolation } \\
\text { rate \% }\end{array}$} \\
\hline & No. & $\%$ & No. & $\%$ & No. & $\%$ & & \\
\hline S. aureus & 50 & 40 & 0 & 0 & 0 & 15.6 & 60 & 28.04 \\
\hline P. multocida & 5 & 4 & 1 & 4 & 5 & 7.81 & 11 & 5.14 \\
\hline P. haemolytica & 3 & 2.4 & 1 & 4 & 0 & 0 & 4 & 1.87 \\
\hline Ps. aeruginosa & 0 & 0 & 0 & 0 & 15 & 23.44 & 15 & 7.00 \\
\hline E. coli & 50 & 40 & 15 & 60 & 25 & 39.06 & 90 & 42.06 \\
\hline Proteus & 15 & 12 & 5 & 20 & 5 & 7.81 & 25 & 11.68 \\
\hline Citrobacter & 2 & 1.6 & 3 & 12 & 4 & 6.25 & 09 & 4.21 \\
\hline Total & 125 & 100 & 25 & 100 & 64 & 100 & 214 & 100 \\
\hline
\end{tabular}

Table (5): The total bacterial groups in examined cattle.

\begin{tabular}{||l||c|c||c|c||c|c||}
\hline \multirow{2}{*}{ Bacterial group } & \multicolumn{2}{|c|}{ Slaughtered cattle (200) } & \multicolumn{2}{|c||}{ Living ones (100) } & \multicolumn{2}{|c|}{ Total (300) } \\
\cline { 2 - 7 } & No. & $\%$ & No. & $\%$ & No. & $\%$ \\
\hline \hline Staph. aureus* & 50 & 40 & 10 & 11.23 & 60 & 28.03 \\
\hline Pasterulla spp.** & 8 & 6.20 & 7 & 7.89 & 15 & 7.50 \\
\hline Ps. aureuginos** & 0 & 0 & 15 & 16.85 & 15 & 7.50 \\
\hline E. coli** & 50 & 40 & 40 & 44.90 & 90 & 42.05 \\
\hline Proteus** & 15 & 12 & 10 & 11.23 & 25 & 20.56 \\
\hline Citrobacter** & 2 & 1.52 & 7 & 7.84 & 9 & 4.20 \\
\hline \hline Total & $\mathbf{1 2 5}$ & $\mathbf{5 8 . 4 1}$ & $\mathbf{8 9}$ & $\mathbf{4 1 . 5 9}$ & $\mathbf{2 1 4}$ & $\mathbf{1 0 0}$ \\
\hline \hline
\end{tabular}

* Gram positive group.

** Gram negative group.

Kafrelsheikh Vet. Med. J. Vol. 7 No. 1 (2009) 
Table (6): Results of antibiotic sensitivity test to some pathogenic representative bacterial strains ( 8 isolates of each type m.o.).

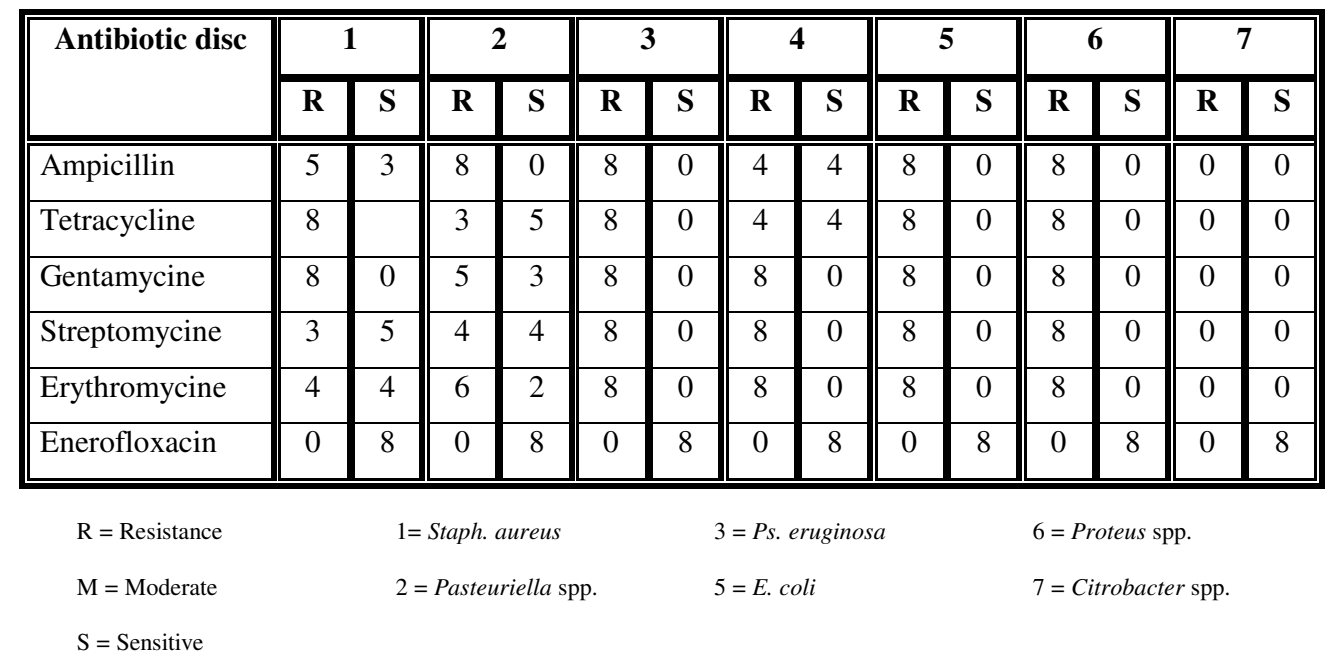

\section{DISCUSSION}

The results emphasize the role of bacterial pathogens as a complicating cause in respiratory diseases in cattle. The results agreed with the obtained ones by Palatary and Newhall (1985).

Examination of 300 samples (Lung and Nasal swabs) from affected cattle revealed that $76.67 \%$ of them were harboured pathogenic bacteria such high incidence of isolation was also reported by Zaid (1996).

The obtained results revealed that Staph. aureus isolated percentage $28.09 \%$ were agreed with the results obtained by Abo-Aikhail and ElNaenaeey (2003). While E. coli isolates percentage (42.06\%) was higher than obtained by Abo-Aikhail and El-Naenaeey(2006)due to these cattle reared and sever stress and less nutrition some of strains of Pasteuriella species were resistant and some other ones were sensitive to ampicillin, tetracycline, gentamycine, strepomycine and erythromycine, these results are like to results obtained by Ungureanu et al. (1988). 
Pasteurella species incidence(7.01\%)in this study was high to obtained by Al-Human et al. (2004) due to sever stress factors affected on the cattle in our study.

The incidence of other obtained bacterial agents were $7.5 \%$ (Ps. aureuginosa), 2.56\% (Proteus species) and 4.20\% (Citrobacter species), which nearly agreement with the other one obtained by Abo-Aikhail and El-Naenaeey (2003).

This study results were revealed that most of the examined strains were all resistant to Ampicilline tetracycline, genamycine, streptomycine and Erythromycine which agreed with Abo-Aikhail and El-Naenaeey (2003) and more sensitive to enerofloxacine.

\section{REFERENCES}

- Abo-Aikhail, A. El-M. and El-Naenaeey, E.Y. (2003). Studies on terobic bacteria causing respiratory infections in cattle with special reference to zoonotic importance. Suez Canal. Vet. Med. J., VI (2).

- Al-Humam, N.A.; Al-Dughaym, A.M.; Mohammed, G.E.; Housam, E.M.; Gameel, A.A. (2004). Study on the isolation and pathogenicity of pasteurella multocida type A. in calves in Saudi Arabia. Pakistan J. of Biological Sciences 7(4): 460-463.

- Barbour, E.K.; Nabbutt, N.H.; Hamadeh, S.K. and Al-Nakhli, H.M. (1997). Bacterial identity and characteristics in health and unhealthy respiratory tracts of sheep and calves Vet. Res. Commun, 21(6), 421430. 
- Blood,D.C.and Henderson,J.A.(1974). Veterinary Medicine $9^{\text {th }}$ Edition. The English Language book Scoiety and Ballere Tindall.

- Burdy, C.W.; Raleigh, R.H.; Collins, I.K.; Watts, J.L. and Straus, D.C. (1997). Serotyping and enzyme characterization of Pasteurela haemolytica and Pasteurella mulocida isolates recovered from pneumonic lungs of stressed feeder calves. Curr. Microbiol., 34(4), 244-249.

- Collin, J.K.; Jensen, R.; Smith, G.H.; Flack, D.E. Kerchen, R.; Bennen, B.W.; Jones, R.L. and Alexander, A.F. (1988). Association of bovine respiratory syncytial virus with atypical interstitial pneumonia in feeder cattle. Am. J. Vet. Res. 79(7), 1045-1049.

- Ehiers, I.; Schimmel, D.; Sachse, K.; Boehnke, H.. and Schoss, P. (1993). Toxin-producing pasteurellae in a cattle herd. Disch. Tierarzil. Woch-Henschr. D.T.W., 100 (12), 488-491.

- El-Enbaawy,M.(1984). Investigation on some microbiological causes of respiratory affection in buffalo calves. M.V.Sc. Thesis (Microbiology) Fac. of Vet. Med. Cairo-University.

- Finegold, S.M. and Martin, W.I. (1982). Diagnosis microbiology $6^{\text {th }}$. C.V. Mosby Co. St. Louis, Toronto London.

- Fisher, W.(1975). Diagnosis and treatment of possibilities of laryngealaffections in calves DSCH. Teranz Wochenschr, 85(6), 168-170.

- Garious, Sandu, I.; Istrate, N. and Faure, C. (1982). Haemophilus-like bacteria isolated from calves and lambs.Revta Crest.Animal,32,50-55. 
- Koneman, E.W.; Allen, S.D.; Dowell, V.R. and Sommers, H.M. (1983). Colour atlas and textbook. of Diagnostic microbiology. $2^{\text {nd }}$. Edn. J. B. Lippincotttc. New York, London.

- Krieg, N.R. and Holt, J.G. (1984). Bergey's Manual of systematic bacteriology. Vol. 1 William and Wilkins Baltmore-London.

- Palotary, J. and Newhall, J. (1985). Pneumonia in newly weaned calves. J. Am. Vet. Med. Assoc., 133, 353-399.

- Singh, S.P. and Singh, N.P. (1980). Milk aspiration pneumonia in Cals" Indian Journal of Animal Science, 50(10), 880-888.

- Ungurenv, C.; Jordach, A.; Eiruinger, U.; Lican, C. and Coman, I. (1981). Pasteurella infections in respiratory diseases of y young cattle. Pasteru Vet. Res. Inst. Sos., Giulesti 333, Sector 7, Bucharest, Romania.

- Virtala, A.M.; Mechor, G.D.; Gron, Y.I.; Erb, H.N. and Dubovi, E.J. (1996). Epidemiologic and pathologic characteristics of respiratory tract disease in dairy beifers during the first three months of life. J. Am. Vet. Med., Assoc. 208(12), 2085-2042.

- Zaid, A.A.A. (1996). Studies on respiratory affections in cattle. Vet. Med. J. Giza 44(3), 619-628. 


\section{عزل وتصنيف المسببات البكتيرية المعزولة من الأبقار التى تعانى أعراض تنفسية د/طلت حامد شعيشع بلير}

باحث أول بمعه بحوث صحة الحيوان / معمل بيطرى كفرالثيخ ــ أحياء دقيقة

أجريت هذه الدر اسة لمعرفة دور البكتريا فى الإصابات التتفسية للماثية وقد تم تجميع 300 عينة من الجهاز التنفسي بهذا المرض الذي يصيب الماثشية منها 200 عينة من المانشية المذبوحة، 50 عينة من المانشية السليمة ظاهريا، 50 عينة من الحيو انات المصابة بأعر اض تتفسية. وقد تبين من نتائج هذه الدراسة أوضحت بأن عدد العينات المصابة بالمسببات البكتيرية كان 150 (65.22\%) من إجمالي 200 عينة مأخوذة من أبقار حديثة الذبح، 80 (34.78\%) من حيو انات سليمة ظاهريا (عدد 50)، و عدد الحيو انات المصابة بالمسببات البكتريا 230 حيو ان بنسبة ( 76.67\% بعض الحالات المصابة نم عزل منها أكثر من ميكروب بكتيرى والأخر واحد فقط، كما أوضحت هذه الدراسة أنه نم عزل أنواع عديدة من الميكروبات البكتبرية كالتالي: الميكروب العنقودى 60 (28.04\%)، القولوى 90 (42.06\%) ، البروتيس 25 (11.66\%)، و الباستير لا 15 ( 7.01\%)، ستروبكتر 9 (4.21\%) و أيضا ميكروب السيدوموناس إريجنوزا 15 (7.0\%) وتنين من هذه الدراسة أن أغب كل العز لات البكتيريا حساسة لمضاد الإنروفلوكساسين ومعظمها غير حساسة لمضاد الأمبسلين. 